\title{
The Dutch system of workers' participation
}

\author{
J.M.B. (Jan) Cremers
}

\section{(2) OpenEdition}

\section{Journals}

Electronic version

URL: https://journals.openedition.org/rdctss/1779

DOI: $10.4000 /$ rdctss. 1779

ISSN: 2262-9815

\section{Publisher}

Centre de droit comparé du travail et de la sécurité sociale

\section{Printed version}

Date of publication: 1 December 2018

Number of pages: 100-107

ISSN: $2117-4350$

\section{Electronic reference}

J.M.B. (Jan) Cremers, "The Dutch system of workers' participation", Revue de droit comparé du travail et de la sécurité sociale [Online], 4 | 2018, Online since 01 November 2021, connection on 15 November 2021. URL: http://journals.openedition.org/rdctss/1779 ; DOI: https://doi.org/10.4000/rdctss.1779

\section{(c) (i) (9)}

Revue de droit comparé du travail et de la sécurité sociale est mise à disposition selon les termes de la Licence Creative Commons Attribution - Pas d'Utilisation Commerciale - Pas de Modification 4.0 International. 


\title{
THE DUTCH SYSTEM OF WORKERS' PARTICIPATION
}

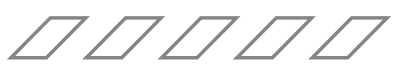

\begin{abstract}
The contribution, the Dutch system of workers' participation, describes the main architecture of the institutionalised system of workers' representation in the Netherlands. In the after WWII-period, the Dutch legislator and the social partners have developed a conventional and regulatory frame that defines and recognises the partners at company level, provides minimum requirements for a dialogue and promotes the negotiations in the shadow of the law. The contribution focusses on three main forms of representation, respectively the work of trade unions at plant level, the rights and competences of works councils and the employee board level representation. The author concludes that the representation in the two-tier supervisory board is much weaker than in countries like Germany, Austria, or Sweden. However, the works council system is well-advanced and equipped with rather strong competences, based on consultation and consent rights on items and policies that are often decided in other countries at the level of the supervisory board. Trade unions tend to rely on the direct participation in the board in situations of high urgency, whilst the daily matters are dealt with in works councils. If the choice has to be made between strengthening the position of works council in codetermination or broadening of the supervisory board towards more workers' participation, the trade unions have so far clearly opted for the first option.
\end{abstract}

KEY WORDS: Industrial Relations, Workers' Participation, Corporate Governance, Works Councils, Social Dialogue.

\section{RÉSUMÉ}

Cet article décrit l'architecture du système institutionnalisé de représentation des travailleurs aux Pays-Bas. A l'après-guerre, le législateur néerlandais et les partenaires sociaux ont élaboré un cadre conventionnel et réglementaire qui définit et reconnaît les partenaires au niveau de l'entreprise, établit les conditions minimales d'un dialogue et encourage les négociations dans l'ombre de la loi. Cet article se concentre sur trois principales formes de représentation, respectivement le travail des syndicats au niveau de l'établissement, les droits et compétences des comités d'entreprise et la représentation au niveau des conseils d'administration. La représentation au sein du conseil de surveillance est beaucoup plus faible que dans des pays comme l'Allemagne, l'Autriche ou la Suède. Cependant, le système des comités d'entreprise est bien avancé et doté de compétences plutôt solides, basées sur des droits de consultation et de consentement sur des éléments et des politiques qui sont souvent décidés dans d'autres pays au niveau du conseil de surveillance. Les syndicats ont tendance à compter sur la participation indirecte au conseil seulement dans les situations de grande urgence. En général, l'accent est davantage mis sur les questions de consultation traitées dans les comités d'entreprise. Si un choix doit être fait entre le renforcement de la position du comité d'entreprise dans la codétermination ou l'élargissement du conseil de surveillance vers une plus grande participation des travailleurs, les syndicats ont jusqu'ici clairement opté pour la première option.

MOTS-CLÉS : Relations industrielles, participation des travailleurs, gouvernance d'entreprise, comités d'entreprise, dialogue social. 


\section{DUTCH SYSTEM OF WORKERS' PARTICIPATION}

\section{DIFFERENT FORMS OF WORKERS' PARTICIPATION}

\section{Direct and indirect involvement}
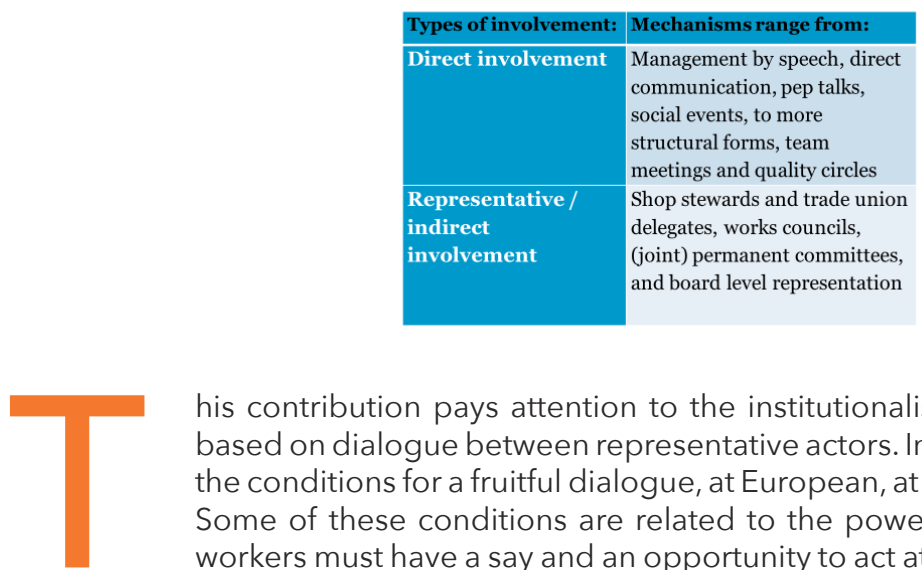

his contribution pays attention to the institutionalised involvement systems, based on dialogue between representative actors. In the past, I have examined the conditions for a fruitful dialogue, at European, at national and at plant level. Some of these conditions are related to the power balance in a company workers must have a say and an opportunity to act at the level where decisions are taken and to talk about issues that really do matter for the company. Other conditions relate to the 'positive' climate for dialogue in a company. Research, dedicated to the quality and impact of the work of works councils, reveals that the stability of the partnership, the fact that workers' input is taken serious and the tradition of consent seeking all contribute to more stable industrial relations at plant level. ${ }^{1}$ Mutual trust and mutual respect, even when positions are diverging, make it possible for management and labour to enter into conflicts, whilst at the same time, the cooperation in other areas continues. It is possible to find some evidence that the stable and structured forms of workers' involvement and dialogue lead to positive labour relations and to better company performance. Thus, the classical HRM-policy of 'looking after the employees' is not enough and the position of the so-called 'scientific management', with workers treated as a commodity, is certainly not a fruitful starting point. Workers' involvement and codetermination have to be an integral part of the company culture and a cornerstone for the changes of the work environment, the work organisation and the overall company policy. For this reason, the different 'hypes' around types of direct involvement that occasionally pop up, often in constituencies (like the Anglo-Saxon countries) that have no stable forms of workers' involvement, are left outside.

These considerations lead to the question what the role of the legislator is. If dialogue is key to come to sustainable and tailor-made partnership, to what extent is it than necessary for the legislator to act? Over the years, the Dutch legislator and the social partners have created the building blocks for a flanking regulatory frame that identifies and recognises the partners at company level, provides minimum requirements for the dialogue and promotes the negotiations in the shadow of the law. It is neither perfect nor transferable, and it has some strengths and weaknesses.

1 J. Cremers, 'Management and worker involvement: cat and mouse or win-win?' In N. Kluge and S. Vitols (eds.), The Sustainable Company: a new approach to corporate governance, Brussels, ETUI, 2011. J. Cremers, "The learning works council", Transfer, 3/08, SAGE, 2008. 


\section{I - REPRESENTATION SYSTEMS IN THE NETHERLANDS}

\section{A - TRADE UNION WORKERS AT COMPANY LEVEL/WORKPLACE BRANCHES}

In the development of the workers participation and the workers' voice in the Netherlands, the position of trade union workplace branches has not really been enshrined in the Dutch legislation. The present-day situation has been settled in the 1970s. In an important advise of the SER (the social-economic council that is the main advisory body for the government), the social partners took the position that the legal frame for the trade union work of a workplace branch had to be restricted to some general provisions, such as the legal protection of the trade union representatives at plant level. ${ }^{2}$ According to the SER, the very nature of the work, the provisions and the size of the facilities for such work had to be addressed by the partners in collective bargaining, not by the legislator. The social partners agreed not to work towards a formal concertation structure for trade union representatives at company level. Over a longer period of time, this resulted in no strict legal frame for trade union work at company level.

In practice, the partners in collective bargaining can agree on how this trade union work is structured and financed. A majority of collective agreements provides representatives of workplace branches with legal protection and (most often limited) facilities. Some of the collectively agreed provisions related to activities of trade union representatives can be made generally binding by the Act on collective bargaining (Wet AVV), such as the definition of trade union work at company level, the right to nominate trade union contact persons, special protection for representatives, participation in collective bargaining, training facilities and (paid or unpaid) days off for trade union meetings and conferences. However, other provisions that may be agreed collectively, cannot be made generally binding, for instance, the entrance of trade union officers, premises and publication facilities, company visits or meetings inside the company.

As a result, the trade unions' presence at plant level is modest, with the exception of some traditional larger plants and companies where workplace branches have been negotiated and trade union units were and are active. In most companies, the trade unions have focussed on the representative work in the works councils (form b, see below). In general, the works councils developed for the unions into the body with the major role and impact. The existing trade union workplace branches function often as the backbone of the trade union delegations in the work councils. The representatives at this level serve as contact persons, provide information on trade union policies, function as ombudsmen and speak on behalf of the colleagues in the trade union ranks. A task that became more and more important over the years was the participation in collective bargaining processes; from the mid-1990s, decentralisation of bargaining became topical. ${ }^{3}$

\section{B - WORKERS COUNCILS}

In the Dutch industrial relations, the main workers' voice is the works council. Some of the characteristics of the work council can be derived from the specific Dutch development

2 Advies inzake het vakbondswerk in de onderneming (Advice on trade union work at company level), SER, 1977, The Hague. https://www.ser.nl/ /media/db adviezen/1970 1979/1977/b05312.ashx

3 The Dutch social partners published in 1997 an overview of the tasks that were concluded in the collective agreements. The paper formulated considerations and recommendations for the future, including a more prominent role in decentralised bargaining. Stichting van de Arbeid (Labour foundation), The Hague, 1997. http://www.stvda.nl/ /media/Files/Stvda/ Aanbevelingen/1990 1999/1997/19970422.ashx 
of capitalism and the welfare state. The nation was for a long time dominated by trade. After the late start of industrialisation, the parliament concluded the first labour legislation in 1875 (the Act against child labour). Two decades later, the first 'modern' trade unions were established (the diamond workers in 1894, the first national trade union confederation in 1906). Until the World War II, two types of voluntary workers' voice were already present in some larger companies: the plant councils and the company core group. The plant councils controlled the compliance with collectively agreed wages and working conditions, whilst the company core group acted as an association of the workers in a company that negotiated agreements with the local company leadership. The Dutch Works Council Act (hereafter WOR), concluded by the legislator in 1950, combined to a certain extent both fundamental objectives. The works council looks after compliance with applicable collective agreements and functions as an interest group/representation of the workers in a company. The works councils started in the post-war period as a platform for concertation. The reconstruction of the country served as the main argument for the search of consensus in the industrial relations. ${ }^{4}$

The Works Council Act prescribes that every undertaking in the Netherlands with at least 50 employees is obliged to set up a works council with a range of information and consultation rights. In addition, undertakings with between 10 to 50 employees are required, by a request of a majority of employees, to set up a personnel representation (PVT). The PVT is a workers' representation with some of the works council competences (this is not treated further in this overview). The WOR prescribes that, where several companies belong to a single group, a central works council (COR) can be set up. Such a COR is composed of representatives of the underlying works councils at plant level or firms. It is also possible to set up an intermediate level works council (GOR) where several businesses groups exist in a single holding company. From 1995 onwards, the WOR applies also to the public sector.

Over the last 65 years, the WOR was reformed several times and the workers' rights and competences that can be derived from the Act have grown substantially. The law provides the works council with three main types of right: information rights, consultation rights and consent rights. In addition, the works council has the right of initiative and competence to make proposals to which the employer must respond. ${ }^{5}$ Moreover, since 1 July 2010, the works councils of public limited companies (both listed and unlisted) have the right to voice their opinion in the general meeting of shareholders (AGM) on major management decisions that have to be approved by the AGM. This right of speech is restricted to decisions with major impact, such as mergers, takeovers and divestments, to the appointment and dismissal of members of the board of directors and the supervisory board (see below), and to remuneration policies. The AGM is not bound to follow the opinion of the works council. ${ }^{6}$

The information rights, formulated in articles 31 to $31 \mathrm{f}$ of the WOR, oblige the management to provide the works council with information on a range of financial/economic issues including the structure and organisation of the company, trends in employment and personnel policy, the company's reporting and accounting and the prospects and longterm corporate plans. In 2006, the legislator added the competence to be informed about the financial compensation of the board members (in article $31 \mathrm{~d}$ ).

The consultation rights, formulated in article 25 of the WOR, relate to economic issues, such as relevant restructurings. Consultation is mandatory if the management plans to

\footnotetext{
4 J. Cremers, Visie op medezeggenschap, The Hague, Elsevier, 'GBIO-Katernen', 2001.

5 R. van het Kaar, F. Vink, Inzicht in de Ondernemingsraad 2017, The Hague, Sdu, 2017.

6 J. Cremers, E. Wolters (eds.), EU and national company law - fixation on attractiveness, Brussels, ETUI, 2011.
} 
sell (parts of) the company, mergers, take-overs, or substantial changes of the activity or organisation of the company. The consultation rights lead to serious delays (up to at least on month) if there is disagreement between the management and the works council. An important instrument in this regard is the right of appeal. The works council can appeal to the Company Chamber of the Court of Appeal in Amsterdam, according to article 26 of the WOR, in case the management has neglected the information and consultation duties, or has taken insufficient account of the interests of the employees. The Company Chamber has the power to block the decision and the planned measures.

Article 27 of the WOR provides the works council with consent rights. The items listed in this article belong to the classical HRM-area, such as consent over pension provisions, working time schemes, wage systematic and scaling, reintegration policy, recruitment and other personnel policies. If the works council disagrees with the planned measures, after at least one consultative meeting between management and works council, the management can ask a district court to overrule the council's position. The court is bound to look at the organisational or economic necessity of the planned measures, and to assess whether the council's position is unreasonable. The district court can declare measures taken by the management without consent null and void, on the initiative of the works council.

\section{II - EMPLOYEE BOARD LEVEL REPRESENTATION (BLER)}

The Dutch Civil Code prescribes that larger companies in the Netherlands, defined as firms with an issued capital of more than $€ 16$ million, at least 100 employees and a works council (obligatory for companies with more than 50 employees), have to apply an indirect participation of employees at supervisory board level. ${ }^{7}$

\section{A - A CLOSER LOOK AT THE REPRESENTATION IN THE BOARD}

\section{1 - The structure and composition of the board}

The Dutch corporate governance structure is traditionally based on a dualistic governance model (i.e. a two-tier governance structure). Companies with a two-tier governance structure divide the management and supervision between two governing company bodies: the management board and the supervisory board. ${ }^{8}$ According to the Civil Code and the Dutch corporate governance code, the supervisory board has to supervise the policies carried out by the management board and the general affairs of the company and its affiliated enterprises. Among other tasks, the supervisory board should focus on the effectiveness of the company's internal risk management and control systems and the integrity and quality of the financial reporting. The supervisory board, composed of at least three members, appoints and dismisses the management and approves major management decisions. These requirements only apply to companies with a majority of employees in the Netherlands. International groups with the majority of employees outside the Netherlands are exempted from these requirements, although their holding companies for Dutch subsidiaries are covered, be it by less stringent arrangements. The composition of the supervisory board has to guarantee that the requested and intended expertise, background, competencies and independence are present for the board to carry out its

7 Civil Code, Book 2, article 158.

8 Since 2013, the choice can be made for a one-tier governance structure in which a single management board, comprised of executive and non-executive directors and no supervisory board, functions. In this situation, the non-executive directors supervise the executive. Nonexecutive directors and executive directors have joint management responsibility. 
duties properly. Each supervisory board member should be capable of assessing the broad outline of the overall management. The general meeting of shareholders approves the nominations for supervisory board members. The AGM can reject the supervisory board's nominations but it cannot nominate candidates itself - only the supervisory board can do this. If the supervisory board's nominations are rejected it must nominate new candidate(s). The basic principle is that supervisory members are appointed for two four-year periods (this can be prolonged). Any subsequent reappointment must be accounted for in a report of the supervisory board. ${ }^{9}$

The supervisory board's terms of reference should include a paragraph dealing with its relations with the management board, the AGM, the workers' representation body in the company (such as the works council) and the executive committee. The chair of the supervisory board has the explicit task to develop proper contacts with the works council. New members have to be made familiar with existing workers' involvement structures.

The competence to decide on the composition of the supervisory board lies in the hands of the AGM. The AGM may pass a resolution to cancel the nomination for the appointment of a member of the management board or of the supervisory by an absolute majority of the votes cast. Employees, large shareholders, (former) clients or (former) managers of a company are excluded from the supervisory board. The main argument is that members of the supervisory board may not act as representatives of partial interests, be it the interests of shareholders, banks or employees. Members of the supervisory board should act in the interest of the company and the undertaking as a whole. A supervisory board member is considered not to be independent if, in the five years prior to an appointment, he or she has been an employee or member of the management board.

\section{2 - The work's council right to nominate}

The corporate governance structures in the Netherlands provide the works council in certain cases with nominating rights for up to one third of the seats on the supervisory board. ${ }^{10}$ Moreover, the works council has the right to be heard by the supervisory board before all supervisory board nominations are handed over to an AGM. This creates the possibility to exert an influence on the composition of the supervisory board. In order to reach one third of the members of the supervisory board, the works council has the right to nominate for every other vacancy, until the one-third proportion is reached. This right applies in both national company entities (the ' $n v$ ' and the 'bv') that have installed a supervisory board according to the statutory two-tier rules of the so-called structure regime. The others conditions are an issued capital of more than $€ 16$ million, at least 100 employees and an existing works council. However, a voluntary application is possible in other companies.

The works council cannot nominate one of its members. As said before, employees of a company or directly in bargaining involved trade union officers are excluded from the nomination into the supervisory board. As a consequence, works councils often rely in the nomination for the board to candidates that have demonstrated a certain commitment to the workers interests (former trade unionists, politicians, industrial relations and human resources experts). But another consequence is of course that the board members have some distance to the practical daily business and policy issues that the works council is dealing with.

The law dictates that, in principle, the supervisory board accepts the nomination and hands it over to the AGM for a final approval. The supervisory board can object to the

9 The revised Dutch Corporate Governance Code 2016, as published by the Corporate Governance Code Monitoring Committee, The Hague, 2016. http://www.mccg.nl/?page=4738

10 Civil Code, Book 2, article 158.5 and 158.6. 
nomination in two cases: the candidate is unqualified for the tasks as a board member or the nomination leads to an imbalanced composition of the board. The supervisory board is obliged to discuss these objections with the works council, in an effort to reach consensus on the nomination. If this fails, the supervisory board has the possibility to appeal to the Company Chamber of the Court of Appeal in Amsterdam and ask for the rejection of the nomination. If rejected, the works council has the right to come up with another candidate. Objections from the side of the works council related to other nominated board members are brought to the attention of the AGM, without further impact. The shareholders can reject a nomination by the works council that is brought before the AGM by an absolute majority of the votes cast at the meeting, provided that at least one third of the capital shares are represented. There is no appeal foreseen to a rejection by the AGM in the Civil Code. It is up to the supervisory board to start with a new procedure. The legislation permits the supervisory board, the general meeting of shareholders and the works council to agree on more far-reaching arrangements, although the right of the shareholders to reject a nomination cannot be removed. In some companies, the nomination right has been enhanced as a result of collective bargaining or more stringent formulations in company statutes. ${ }^{11}$

Another influence can be exerted through the formulation of the profile of the board member. Nominations must come from the supervisory board in line with a desired profile of the composition of the board. The supervisory board has the obligation to discuss this supervisory board profile with the works council at the start-up of the board and when modifications are formulated. ${ }^{12}$ This profile contains not only the composition of the board, but also the regulation of the nomination by the works council and the requested quality and expertise.

A last provision that has to be mentioned here is the right of the works council to request the dismissal of a supervisory board member. The work council can appeal to the Company Chamber of the Court of Appeal in Amsterdam and ask for such a dismissal - a right that is rarely used. The grounds are the neglecting of the prescribed tasks, significant arguments or the structural change of the company that makes a person no longer the right board member.

The practical experiences with these nomination rights are mixed. Very often the supervisory board is composed of five members; with the consequence that only one board member is nominated by the works council. Earlier research also suggests that works councils not make full use of their nomination rights. The actual total number of employee representatives in the board may lay well below $150 .{ }^{13}$ Van het Kaar gives several reasons for this phenomenon. One is resistance by the acting supervisory (and often management) boards; dislike of 'strangers'. The boards just go their own way, neglecting (and in a formal sense violating) works council rights, or pushing works councils to accept their own preferred candidates (sometimes labelling them as having been nominated by the works council). From an employee point of view, a second reason seems more important: either works councils are not aware of their rights or, more relevant, they consider them as being not very powerful, and at least less powerful than their rights deriving from the Works Council Act. In a material sense, this may very well be a valid argument: workers and union officials are not allowed on boards, board members may not represent specific interests

11 See for instance the NRC-case, https://uitspraken.rechtspraak.nl/inziendocument?id=ECLI:NL:RBAMS:2014:5462

12 Civil Code, Book 2, article 158.3.

13 Estimated by R. van het Kaar, 'Chapter 11 - The Netherlands', in J. Cremers and S. Vitols, Exercising voice across borders: worker rights under the EU Cross-border Mergers Directive, Brussels, ETUI, 2018 (forthcoming). 


\section{DUTCH SYSTEM OF WORKERS' PARTICIPATION}

(including worker interests), and works councils can only nominate, and not appoint, board members. According to van het Kaar, Dutch rights with regard to board level representation are much weaker than in for instance in Germany, Austria and Sweden.

\section{3 - Changes over the years}

There have been relatively few changes in the corporate governance structure in the past decades in the Netherlands. The most important change took place in 2004. In that year the Dutch system of board-level representation was altered. The balance of power in so-called 'structure regime' public limited companies shifted from the supervisory board to the general meeting of shareholders. One of the main changes was the right of the AGM to appoint and dismiss the supervisory board. Before 2004, supervisory board members were co-opted by the existing supervisory board. The works council's right to nominate members of the supervisory board was strengthened with an enhanced right that can only be rejected by the supervisory board on two well-defined grounds, but their right to effectively oppose the nomination of a new supervisory board member was lost.

Another change took place in 2013 as the choice between a two-tier corporate governance structure, with a management and supervisory board, and a monistic structure with a single board of directors, was made available to public and private limited companies, including those subject to the structure regime. This change did not touch upon the right of works council to nominate supervisory board members.

\section{FINAL REMARKS}

Speaking about the Dutch situation leads often to debates, especially among academic experts at European level, about functional equivalents. As has been described before, the Dutch system is rather standing on its own. The representation in the two-tier supervisory board is much weaker than in countries like Germany, Austria, or Sweden. On the other hand, is the works council system well-advanced and equipped with rather strong works council competences, based on consultation and consent rights on items and policies that are often decided in other countries at the level of the supervisory board.

Trade unions tend to rely on the direct participation in the board in situations of high urgency, whilst the daily matters are dealt with in works councils. If the choice has to be made between strengthening the position of works council in codetermination and broadening the supervisory board towards more workers' participation, the trade unions have so far clearly opted for the first direction.

\section{J.M.B. (JAN) CREMERS}

Partner at the Faculty of Law, Tilburg, Institute of Advanced Studies, Amsterdam (AIAS). Former European trade union leader and member of the European Parliament. Honorary Doctor of Letters at the University of Westminster «in recognition of his services to European social policy».

Research topics: Workers' participation, European social law, company law, collective rights of workers.

\section{Publications:}

J. Cremers, S. Vitols et M. Stollt, A Decade of experience with the European Company, ETUI, Bruxelles, 2013.

J. Cremers, S. Vitols, Takeover with or without worker voice : workers' rights under the EU takeover bids directive, ETUI, 2016.

J. Cremers et S. Vitols, Exercising voice across borders: worker rights under the EU Cross-border Mergers Directive, Brussels, ETUI, 2018 (à paraître). 